\title{
Enkle tiltak kan redde nyfødte
}

\section{Opplæring av helsepersonell til å stimulere og maske/bag-ventilere nyfødte i forbindelse med fødsel kan redusere nyfødtdødeligheten med mer enn $40 \%$.}

På verdensbasis dør hvert år ca. 8 millioner barn under fem år, de fleste i ressursfattige land. Av disse er ca. 3,5 millioner nyfødte.

- Enkle tiltak i forbindelse med fødsel kan redde mange liv. Skal tiltakene ha effekt på global barnedødelighet, må de være «lavteknologiske» og billige, slik at de kan iverksettes hvor som helst i verden: Overvåking av fosterlyd med økt bruk av jordmorstetoskop vil fange opp utsatte barn som trenger hjelp, og hvis den nyfødte ikke puster selv, vil rask stimulering og eventuelt maske/bag-ventilering redde de fleste, sier Hege Langli Ersdal.

Hun har sett på data fra 10271 fødsler ved et sykehus i Tanzania, hvor trente assistenter har observert og registrert alle fødsler siden 2009.

- Data viser at $16 \%$ av de nyfødte ikke begynte å puste selv. Nesten halvparten av dem trengte kortvarig maske/bag-ventilering i tillegg til stimulering før de startet å puste. Dette må skje raskt: For hvert halve minutt som går etter fødsel uten at barnet puster selv eller noen puster for barnet, øker sannsynligheten for død eller sykelighet med $16 \%$, sier Ersdal.

- Våre studier fra Tanzania viser at enkel simuleringsbasert kursing - «Helping Babies Breathe» - HBB - har ført til at nyfødtdødelighet de første 24 timene nå er redusert med $47 \%$, og andel «dødfødsler» er redusert med $24 \%$. Den nylig publiserte studien fra åtte sykehus i Tanzania viser at antall spedbarn som dør i forbindelse med fødsel, nesten halveres - fra 1,7 \% til 0,9 \% - når helsepersonell er opplært etter HBB-programmet og bruker teknikkene. Dette simuleringsopplegget kan virkelig bidra til å redusere nyfødtdødeligheten. Helsepersonell verden over bør kurses hvis tusenårsmålet skal nås, sier Ersdal.

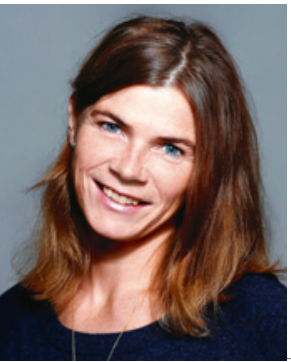

Hege Langli Ersdal. Foto Kjetil Alsvik

Disputas

Hege Langli Ersdal disputerte for ph.d-graden ved Universitetet i Oslo 21.11. 2012. Tittel på avhandlingen er Appropriate interventions to reduce perinatal mortality and morbidity in lowresourced settings. Fetal heart rate assessments and basic actions at birth.

\section{Infeksjoner i kunstige hofteledd}

\section{Mange nordmenn får satt inn en hofteprotese til erstatning for et slitt eller $\varnothing$ delagt hofteledd. Infeksjoner rundt disse protesene er blitt et økende problem.}

Hvert år får vel 11000 nordmenn satt inn en hofteprotese, et kunstig hofteledd, oftest som en følge av slitasjegikt, leddgikt eller lårhalsbrudd. De aller fleste får mindre smerter og bedre funksjon etter operasjonen, men noen få pasienter får alvorlige komplikasjoner. En slik alvorlig komplikasjon er infeksjon rundt protesen.

- Målet med dette doktorgradsarbeidet var å studere endringer $\mathrm{i}$ forekomsten av slike proteseinfeksjoner, hvilke pasienter som er mest utsatt for å få infeksjon, hva som er risikofaktorer, og hvilke tiltak som kan beskytte mot slike infeksjoner, sier Håvard Dale, spesialist i ortopedisk kirurgi på Ortopedisk klinikk ved Haukeland universitetssykehus.

Studien omfattet hofteprotesepasienter som i perioden 1987-2011 er blitt registrert i Nasjonalt register for leddproteser, Nasjonalt hoftebruddregister, Norsk overvåkingssystem for antibiotikabruk og helsetjenesteassosierte infeksjoner (NOIS), Norsk pasientregister og/eller den nordiske leddproteseregisterforeningen (NARA).
Tre prosent av pasientene fikk en eller annen form for sårinfeksjon etter hofteproteseoperasjonen, mens knapt én prosent av pasientene ble operert på nytt på grunn av infeksjon rundt protesen.

- Til tross for mange forebyggende tiltak synes infeksjonsforekomsten i kunstige hofteledd å øke. I dag er det over tre ganger så høy fare for at pasienten må reopereres på grunn av proteseinfeksjon som tidlig på 1990-tallet. Forklaringen på denne økningen kan være at bakteriene som gir infeksjon, er blitt mer motstandsdyktige mot forebyggende tiltak. Grunnen kan også være at flere av pasientene som nå får proteser, har sykdommer som øker risikoen for infeksjon. Noe av årsaken kan også være at legene er blitt flinkere til å påvise og rapportere infeksjoner, avslutter Dale.

\section{Tone Bergset}

tone.bergset@legeforeningen.no

Tidsskriftet

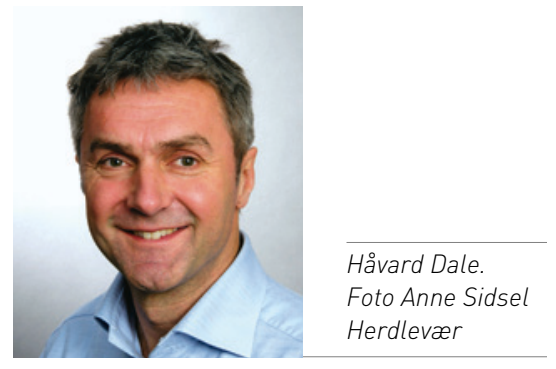

Disputas

Håvard Dale disputerte for ph.d.-graden ved Universitetet i Bergen 8.2.2013 med avhandlingen Infection after primary hip arthroplasty; epidemiology, time trends and risk factors in data from national health registers. 